\title{
Anna-Elena Pääkkölä
}

\section{SADOMASOKISTISET VOIMASUHTEET MUSIIKISSA}

Tässä artikkelissa analysoin sadomasokistisesta näkökulmasta Cole Porterin laulua So in Love. Tarkastelen sekä nuottikuvaa, että kahden eri artistin tulkintaa laulusta. Sadomasokismia musiikissa ei ole aikaisemmin tutkittu juuri ollenkaan, todennäköisesti siksi, että sitä on kauan pidetty perversiona normaalin (sic) seksuaalisuuden kentässä. Tieteellinen tutkimus on alkanut haihduttaa tätä stigmaa vasta noin 25 vuotta sitten. Sadomasokismi-käsitettä (lyhennettynä sM) ei ole sovellettu musiikkitieteellisissä analyyttisissa tulkinnoissa kovinkaan paljoa, vaikka sM-spesifejä sanontoja viljellään gender-painotteisissa musiikkitieteellisissä tulkinnoissa. Esimerkiksi sanat submissio, dominointi, rangaistus vilahtelevat monen sukupuolentutkimusta käyttävän musiikkitieteilijän teksteissä. Susan McClary (2002: 59) kutsuu Carmenia dominatrix-sanalla. Lawrence Kramer (1997: 126-127) kuvailee puolestaan Madame Butterflyn yleisön suhtautumista pääosaan sadistiseksi. Susan G. Cusick (2006: 78) puhuu musiikin kuuntelusta vallanvaihdon ja intimiteetin virtauksena mielihyvän kautta. Fred Maus (2004: 35) kirjoittaa jo sadismin ja masokismin tavasta erotisoida fyysistä kipua, muttei vielä ehdota suoraa yhteyttä musiikkiin. Norjalainen Jon Mikkel Broch Ålvik tutkii pro gradu -tutkielmassaan miesmasokismia populaarimusiikissa, ja Judith A. Peraino (2006: 242-243) tulkitsee kirjassaan Listening to the Sirens Marilyn Mansonin musiikkia muun muassa sadomasokismin näkökulmasta. Sadomasokismiin viittaavia tulkintoja on siis jo noussut esiin musiikkitieteessä, muttei vielä virallisesti, omalla nimellään. Monet tutkijat ovat jo huomanneet psykologiset 
suhteet musiikin ja vallan välillä, mutta missään vaiheessa ei tätä valtasuhdetta ole kutsuttu (tai uskallettu kutsua) sadomasokistiseksi.

Analyysin tarkoituksena on tuoda uudenlaista näkökulmaa musiikin analyysiin, tulkita siinä tapahtuvia valtasuhteita sadomasokistisin termein, ja osoittaa yksi uusi mahdollinen tapa, miten musiikkia voidaan tulkita. Tarkoituksena on löytää uudenlaisia ideoita eroottisen musiikin määritelmään, sekä kenties antaa osviittaa sille, miten aiemmin ei-eroottiseksi tulkittu musiikki voitaisiin tulkita uudelleen. Metodologiaksi olen valinnut hermeneuttis-fenomenologisen musiikkitieteellisen lähestymistavan yhdistettynä feministiseen, eritoten queerteoriasta lähtöisin olevaan tarkastelun tapaan. Queer-teorialla on ollut vaikutus kulttuuriseen musiikkitieteeseen jo noin kaksikymmentä vuotta, ja sitä on Suomessa käyttänyt tutkimuksissaan mm. John Richardson, Anne Sivuoja, Susanna Välimäki, ja Juha Torvinen. Metodini pohjautuu myös Eve Kosofsky Sedgwickin (2003: 130) "paranoid reading"-tekniikkaan, jota voisi kutsua paranoidiseksi lukemiseksi. Sen pääpiirteenä on vahva alustava teoria, jonka oikeaksi tai vääräksi todistelemista tieteellinen prosessi on. Tutkimus- ja analyysimetodina paranoidi lukeminen jää helposti spesifiksi ja tautologiseksi, ja siksi se on hyvä täydentää reparatiivisella lukemisella (Sedgwick 2003: 137), joka osoittaa miten paranoidi analyysi tehdään hyödylliseksi ja sovellettavaksi. Siksi analyysini on kaksivaiheinen: musiikkianalyysi (paranoidi osio) sekä laulun kahden erilaisen esityksen analyysi (reparatiivinen osio).

\section{Sadomasokismi}

Sadomasokismi on hybridi termeistä sadismi ja masokismi. Sadismi on yleensä määritelty seksuaalisen mielihyvän saamiseksi toisiin kohdistuvasta kivun tuottamisesta (Krafft-Ebing 1995: 25; Freud 1995: 33). Krafft-Ebing ja Freud, ensimmäiset akateemikot jotka sadomasokismista kirjoittivat 190o-luvun alun molemmin puolin, pitivät sadismia perversiona, jopa jonkinlaisena patologiana. Sadismi oli läheisessä yhteydessä masokismiin, seksuaalisen mielihyvän saamiseen kivun ja nöyryytyksen kautta (Krafft-Ebing 1995: 28-29; Freud 1995: 34). Sadismi on saanut nimensä ranskalaiselta kirjailijalta, markiisi de Sadelta, joka kuvasi romaaneissaan sadistisia seksuaalisia käytäntöjä (Ellis 1995: 37-38), kun taas masokismin termin nimesi Krafft-Ebing (1995: 29) kirjailija Leopold von Sacher- 
Masochin mukaan, joka ensimmäisenä kuvasi masokistisia taipumuksia romanttisessa kanssakäynnissä. Sadismi ja masokismi pysyivät kauan saman ilmiön erilaisina puolina, ja niiden sanottiin jopa olevan yhtäaikaisesti läsnä henkilössä jolla näitä taipumuksia esiintyi (Freud 1995: 34-35). Gillez Deleuze (2006: 39-40) erotti nämä viimein toisistaan itsenäisiksi käsitteiksi. Koska sadismi ja masokismi ovat usein keskenään vaihdettavissa olevia ilmiöitä, Deleuze (2006: 46) näkee niiden siis olevan "pelkästään analogisessa yhteydessä" sekä "kokonaisia itsessään" (Deleuze 2006: 67).

Nykyään sm kantaa yhä perversion stigmaa valtaväestön keskuudessa, mutta tiedemaailma alkaa tunnistaa sen seksuaalisena preferenssinä tai elämäntyylinä (Weinberg \& Kamel 1995: 20), seksuaalisuutena (Califia 1995: 139), tai jopa seksuaalisena "leikkinä" (Kleinplatz \& Moser 2006: 9). Termien "sadisti" ja "masokisti" sijasta käytetään nykyään heidän valtapositiotaan seksuaalisen leikin kontekstissa ilmaisevia termejä; dominoiva (dom, Master, top) ja submissiivinen (sub, orja, bottom). sM nähdään "vallan vaihtona" (power exchange; Weinberg 2006: 33). Weinberg, William \& Moser määrittelevät sadomasokismin viidellä reunaehdolla joiden lähtökohtana on, että SM on käyttäytymistapa. Jokaisen aspektin ei tarvitse olla läsnä sM-suhteessa, mutta yleensä kaikki viisi löytyvät. Nämä ovat:

1. Dominoinnin ja submission ilmiö; ilmiö yhden kumppanin vallasta toisen yli.

2. Roolipeli.

3. Molemminpuolinen suostumus osallistua sM-vuorovaikutukseen.

4. Molemminpuolinen määrittely, s. o. jaettu ymmärrys siitä, että aktiviteetit ovat sM-henkisiä tai samantapaisen määrittelytavan henkisiä.

5. Seksuaalinen konteksti; esimerkiksi ajatus siitä, että sm tapahtuu aina seksuaalisessa tilanteessa, ei kaikkien sM-harjoittajien mielestä pidä paikkaansa. (Kleinplatz \& Moser 2006: 4.)

Nämä viisi komponenttia näyttävät hyviltä lähtökohdilta tarkastella sM-teoreettisia tilanteita ja ilmiöitä musiikissa. Pelko tai pakottaminen ei kuulu sadomasokismiin. Vain illuusio väkivallasta on läsnä (Weinberg \& Kamel 1995: 19), ja tämäkin tarkoittaa kipua, joka ei ole tyypillisesti määriteltyä kipua. Nichols (2006: 284) määrittelee sadomasokismiin liittyvän kivun seuraavasti: "Ajattele 'kipua' niin kun rakastajasi näykkäisisi sinua seksuaalisen hurmion keskellä, eikä 
'kipua' niin kuin juurihoidossa. Visualisoi nipistelyä tai raapimista kesken kiihottumisen sen sijaan, että visualisoisit turpaan ottamista." Koska sM-kohtaukset ovat pitkälti ritualisoituja ja jopa käsikirjoitettuja (Kleinplatz \& Moser 2006: 6), toinenkin illuusio on läsnä, nimittäin spontaaniuden illuusio (Weinberg 2006: 34). Kaikki tämä on riippuvaista luottamuksesta subin ja domin välillä, ja siksi edellyttää syvempää kommunikaation tasoa SM-suhteessa (Nichols 2006: 285; Weinberg 2006: 26).

"Safe, Sane and Consensual credo" (turvallinen, selvä- tai tervejärkinen, molemminpuolinen suostumus - credo; Kleinplatz 2006: 339) -sanonnan mukaista sadomasokismissa on myös turvasanametodi, joka antaa subille vallan lopettaa sM-tapahtuman millä tahansa hetkellä, ja dom kunnioittaa tätä aina. Tämä johtaa ehdotukseen siitä, että vallan kahvassa on sittenkin sub eikä dom, varsinkin kun yleensä juuri subin fantasia on se, jota toteutetaan (Love 2000: 88). Sadomasokismia pidetään nykyään interpersonaalisena ja ei-gendersidonnaisena, tai ekumeenisena, kuten Rebecca F. Plante (2006: 62) sitä kutsuu. Se ei ole sidottu seksuaaliseen preferenssiin eli siihen, onko sen harjoittaja homo, lesbo, bi, trans, interseksuaali, queer tai hetero. Se ei ole myöskään sidottu osallistujamäärään.

\section{Subkulttuuri ja queer-teoria}

Queer-teorian puolella on tehty muutamia huomioita sadomasokismiin liittyen, mutta sitä ei ole käsitelty kattavasti. Täten tilanne on samankaltainen musiikkitieteen kanssa. Toisaalta sM-sosiologia tai -psykologia ei ole viitannut teorioissaan queer-teoriaan, mikä kuitenkin perustaltaan näyttäisi olevan hyvin samantapainen sM-teorian kanssa. Näin on varsinkin Michel Foucaultin valtateorioiden ja Judith Butlerin performatiivisuuden kohdalla. Käytänkin näitä teorioita siltana SM-teorian ja musiikin välillä.

Foucaultin (1998: 94) mukaan vallan konsepti sisältää sekä tuottavan että rajoittavan funktion, ja tämä pitää paikkansa myös seksuaalisuuteen liittyvän vallan kohdalla. Tästä päättelen, että kaikkien valtasuhteiden voidaan ajatella sisältävän seksuaalisuuden käsitteen joko kiellettynä, kontrolloituna tai kannustettuna aspektina. Sosiaalisessa valtasuhteessa kielletty seksuaalisuus pitää silti olla läsnä, että se tunnistetaan ja voidaan kieltää. Valta ja kaipuu (desire) ovat täten yhteen liittyneitä, kuten Foucault (1998: 81) toteaa: "Laki sisältää sekä 
kaipuun sekä sen puuttumisen". Täten valta ei itse asiassa tukahduta seksuaalisuutta, vaan puolestaan tuottaa sitä (De Lauretis 1987: 12; Oksala 2007: 69). Kun ajatellaan valtaa osana seksuaalisuutta sekä interpersonaalisena että sosiaalisena ilmiönä, Foucault (1998: 94-96) esittää muutaman väittämän vallan luonteesta, ja tässä niistä itse laatimani lyhennelmät.

- Valtaa ei saada, oteta tai jaeta, vaan sitä harjoitetaan moninaisissa yhteyksissä (myös musiikista; ks. Shepherd 1993: 47).

- Valtasuhteet ovat aina läsnä kaikenlaisissa ihmissuhteissa, joko tuottavana tai kieltävänä aspektina.

- Valta tulee alhaaltapäin; ei siis ole herraa ilman palvelijaa.

- Valtasuhteet ovat sekä intentionaalisia että ei-subjektiivisia.

- Missä on valtaa, siellä on vastustusta, mutta vastustus ei ole valtasuhteiden ulkopuolella vaan tiiviisti sen sisällä vastaanväittäjän ja kriitikon roolissa.

Kun sadomasokistista suhdetta verrataan näihin teeseihin, löytyy niistä monia samankaltaisuuksia. Vallanvaihto ei perustu olemassa oleviin statuseroihin, vaan se luodaan sM-kontekstissa. Siksi sM-suhteen osanottajat sekä luovat että tuottavat valtasuhteen toistensa välille, myös fantasiansa keinoin. Tästä syntyy tuottava (sensuaalinen, seksuaalisesti miellyttävä) vallanvaihto. Valta tulee alhaaltapäin, ja viime käden valta on aina alistuvalla, ei dominoivalla osapuolella. Vallanvaihdon fantasiaan käydään vapaaehtoisesti molemminpuolisen määrittelyn kautta, mutta ei-subjektiivisuus on jokseenkin kyseenalaista tässä vaiheessa. sM-kohtaus voidaan nähdä ei-subjektiivisena ulkopuolelta, mutta itse pitäisin kohtauksen sisäistä fantasiamaailmaa hyvinkin subjektiivisena, ja varsinkin sen tuottamia kokemuksia. Toisaalta, subjektiivisesti nähty vallanvaihto voitaisiin nähdä myös kohtauksen sisällä koskevan koko parisuhdetta, ja siitä tulisi pelottava, "oikea" vallanvaihdos. Fantasia ja kokemus ovat siis subjektiivisia, mutta kohtaus toteutetaan objektiivisesti.

Judith Butler ja hänen ajatuksensa sukupuolesta performatiivina saivat alkunsa Foucaultin ideasta, jonka mukaan sukupuoli on aina konstruoitu kulttuurin sisällä ja sen vallan alaisena, vallan joka määrittää "normaalit" ja "terveet" seksuaalisuuden ilmaisut (Foucault 1998: 155; Oksala 2007: 78). Seksuaalisuus ei siis ole annettu tai sisäänrakennettu psyykeen tai biologiaan. Butler kehitteli ideaa pidemmälle (väärin)lukemalla Foucaultin ajatuksia ja irroittamalla yhteyden 
biologisen, ontologisen sukupuolen (sex) ja kulttuurisen, psykologisen sukupuolen (gender) välillä. Täten sukupuolen kausaalisuus pirstoutuu. Biologinen mies ei välttämättä tarkoita "miespuolista", eikä biologinen nainen "naispuolista" (Butler 1990: 8-9). Itse asiassa kulttuurinen sukupuoli syntyy kulttuurisista konstruktioista, ideoista joita liitetään sukupuoleen, mutta ne eivät ole sidonnaisia ihmisen biologiaan. "Sukupuoli 'on' aina sukua konstruoituihin suhteisiin millä se määritellään" (Butler 1990: 14). Täytyy muistaa, että kulttuurisen sukupuolen määritelmät eivät missään nimessä ole universaaleja tai ikuisia, vaan muuttuvat kulttuurista ja ajasta toiseen. Kun sukupuolesta on saatu näinkin liikkuva konsepti, saavumme Butlerin ajatukseen sukupuolesta performatiivisena konstruktiona.

Performatiivisuus ei ole sama kuin performanssi, vaikka se sanana sen sisältääkin. Teatterissa performanssi on representaatiota, mutta performatiivisuus on sekä presentaatio että representaatio samassa. Butler (1990: 34) määrittelee performatiivisuuden "identiteetin rakentamisena", jonka takana ei oikeastaan ole omaa agentuuria eikä kaikkivoipaa biologista Sukupuolta joka sanelisi sukupuolitetun käytöksen luonnollisena seurauksena itsestään. Taustalla on vain kulttuurisesti konstruoitu representaatio, joka kopioidaan sukupolvelta toiselle. Tämä konstruoinnin järjestys menee itse asiassa päinvastaisessa järjestyksessä kuin on aikaisemmin ajateltu. Sukupuolen ilmaisun takana ei ole olemassa gender-identiteettiä, päinvastoin. Gender-identiteetti konstruoidaan näiden ilmaisujen kautta.

Kun nämä ajatukset sovelletaan sadomasokismiin, sub ja top -positiot ovat tietoisesti tuotettuja performatiiveja. Koska nämä positiot ovat performatiiveja, eivät ne missään nimessä ole sidottuja osallistujien sukupuoleen. Näin saamme essentialisoivat teoriat "aina" dominoivasta miehestä ja alistuvasta naisesta hävitettyä, ja mahdollistamme dominoivan naisen sekä alistuvaan miehen. Itse asiassa, kaikki edellä mainituista ovat performatiivisesti luomassa positiotaan, sekä itselleen että toiselle. Tavallaan, queer-teorian ja sadomasokismin yhdistelmän kautta voitaisiin ehdottaa uudenlaista teoriaa: jos näemme sadomasokismin seksuaalisuuden muotona, niin sen uudet "sukupuolet" tai siihen verrattavat roolit olisivat submissiivinen ja dominoiva, pitäen mielessä että nämä positiot ovat joustavia ja vaihdettavissa keskenään, kuten "miehekkään" ja "naisellisen" positiotkin. 


\section{Sub(limoitu) erotiikka Cole Porterin laulussa So in Love}

Löytääkseni valtastruktuureita musiikin sisällä käytän Sedgwickin paranoidista lukemista ennen esitysanalyysien reparatiivista tulkintaa. Analyyttiseen tulkintaan lisätään uudelleentulkinta, tässä tapauksessa sM-terminologiaan perustuva. Tässä tekniikassa pitää löytää musiikista kaksi tarpeeksi erilaista agentuuria, jotka tähän asti on nähty toisiaan tukevina, ja kääntää niiden suhde performatiiviseksi valtasuhteeksi, jonka jälkeen spekuloidaan molempien sM-positiota. Esimerkkinäni käytän Cole Porterin laulua So in love. Esimerkki saattaa olla helppo, mutta pyrkimyksenäni on osoittaa lyhyellä esimerkillä, kuinka sM-sensitiivinen paranoidi lukeminen olisi mahdollista, ja kuinka sitä voitaisiin soveltaa myös muuhun musiikkiin.

So in love on laulu Cole Porterin musikaalista Kiss me, Kate!. Musikaalin ensi-ilta Broadwaylla oli vuonna 1948. Juoni perustuu Shakespearen näytelmään Kuinka äkäpussi kesytetään. Kiss me, Kate! sekä alkuperäinen Shakespearen näytelmä koskettavat sm-teemoja hyvin läheltä, koska juonen mukaan onnellisuus parisuhteessa saavutetaan (naisen) alistumisen kautta. Musikaalissa tämän laulun laulaa naispääosan esittäjä, mutta en halua tässä vaiheessa ehdottaa sukupuoleen perustuvia analyyseja. Tämä analyysi perustuu melodian ja sointujen erikoiseen suhteeseen, joka voidaan tulkita myös sM-termien kautta. Olen merkinnyt nuottiesimerkkiin yksinkertaiset soinnut sekä niistä "poikkeavat" melodian nuotit, so. nuotit jotka laajentavat soinnut tyypillisiksi jazz-soinnuiksi. En kuitenkaan väitä, että laajemmat soinnut olisivat jotenkin irrelevantteja. Päinvastoin aion tuoda niille uuden tulkinnan melodialinjan avulla. Tässä vaiheessa sointujen yksinkertaistaminen ja niiden vertailu melodiaan on nopeampi ja yksinkertaisempi tapa nähdä melodian erityispiirteet, kun niitä verrataan yksinkertaisimpiin juurisointuihin.

Laulua voisi luonnehtia "torch"-lauluksi, joka tarkoittaa (hiukan ylilyövää ja sentimentaalista) rakkauslaulua, jossa laulajan position (yleensä "minä") on rakastunut (eng."holds a torch" for) laulun objektiin (yleensä "sinä"). Submissiiviset lyriikat (rakkaudelle, rakastetulle) ovat yleisiä tässä perinteessä (Burns 1995: 305). Laulu etenee tutussa AABA-kaavassa, joka on tuttu muoto amerikkalaisissa show-lauluissa. A-osissa on jonkun verran muuntelua keskenään. Jos tarkastelemme Porterin laulua tarkemmin, huomaamme kaavan olevan enemmänkin muodossa A-A1-B-A2, joista A1 and A2 moduloivat As-duuriin, ja A2 on hieman 
pidempi kuin A tai A1 väistämällä viimeistä toonikaa muutaman tahdin laulun lopussa (ks. liite 1). Burns (1995: 303) tulkitsee laulun tavalliseen 32-tahtiseen kaavaan, mutta unohtaa A2-osan pidennetyn lopukkeen. Siksi korjaisin hänen tulkintaansa siten, että laulu soveltaa 32-tahdin kaavaa. Kaikki A-osat alkavat samoin, ja eroavat toisistaan aina samalla kohdalla, jokaisen 1o:n tahdin aikana. Tarkempi katsaus kymmenensiin tahteihin näyttää erojen olevan lähinnä sekvensiaalisia. A1 nostaa melodian sekunnin ylöspäin (b1 - es2) A:han verrattuna (b1 - des2), ja A2 nostaa melodian sekunnin ylöspäin (b1 - $\mathrm{f}_{2}$ ) verrattuna A1:een (ks. esimerkit 1-3). Burns (1995: 312) tulkitsee tämän Schenker-analyysissaan vaiheittaiseksi nousuksi, f2:n ollessa eräänlainen lakipiste laululle. (Kaikki esimerkit on kirjoitettu f-molliin.)

\section{$E^{b}$}

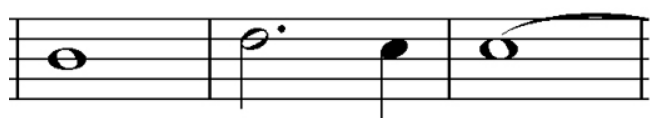

Nuottiesimerkki 1 .

Osa A, tahdit 9-11

(sanat: Stars fill the sky)

Nuottiesimerkkii 2.

Osa A1, tahdit $25-27$

(sanat: [you] know, darling, why)

Nuottiesimerkki 3.

Osa A2, tahdit 57-59

(sanat: [I'm] yours till I die)

Olen merkinnyt melodian "poikkeavat" sävelet sulkuihin nuottiesimerkkiin, so. ne melodian sävelet, jotka eivät sovi perusmuotoiseen sointuun. Ne siis laajentavat yksinkertaisia sointuja jazz-soinnutuksen puolelle. Nopea vilkaisu kertoo, että näitä poikkeussäveliä on useampia. Melodia näyttää menevän omille teilleen, painottaen erikoisempia säveliä kuin soinnun ehdottamat sävelet. Jopa laulun ensimmäisessä tahdissa melodia kohottautuu pienen sekunnin verran ylöspäin soinnun kvintistä (F-mollissa, Cı:ltä Desı:lle, joka on pieni sekunti kvin- 
tiltä ylöspäin) ja tahdissa kolme pienennettyyn sekuntiin (pieni nooni?) sointua vasten (Desı vastaan C7-sointua) McClaryn (2002: 37) "hankaussähkön" mukaisesti ("friction to heat"; ks. myös Scott 2003: 21; Richardson 1999: 179). "Hankaussähköllä" McClary tarkoittaa (yleensä renessanssimusiikissa) kahden läheisen laulustemman pysähtymistä pienen sekunnin päähän toisistaan, ja tämän seurauksena ne stimuloivat toisiaan libidinaalisesti. Olen soveltanut tätä periaatetta laulustemman ja sointusävelten välisiin suhteisiin.

Jos katsomme tätä ilmiötä sadomasokistisesta näkökulmasta, voisiko tämän ilmiön nähdä melodian dominointina ja sointukulun submissiona? Pakottaako melodia soinnut laajempiin jazz-sointuihin vai eikö se suostu tottelemaan sointukulun "pakotusta" ja valitsee "tottelemattoman" alistuvan puolen? Onko palkintona herkullisia "riitasointuja" (ainakin tonaalisen musiikin kielellä puhuttaessa), jotka tuottavat auditiivista mielihyvää, tai ainakin luovat eroa niihin melodian säveliin jotka ovat "samaa mieltä" soinnutuksen kanssa? Onko melodian tottelemattomuus petausta palkinnolle, tottelemiselle? En tietenkään tällä tarkoita, että kaikki jazz-harmoniat, joissa on laajoja sointuja, sisältävät sadomasokistisia viitteitä, vaikka paranoidisesti lukien näinkin olisi mahdollista ajatella.

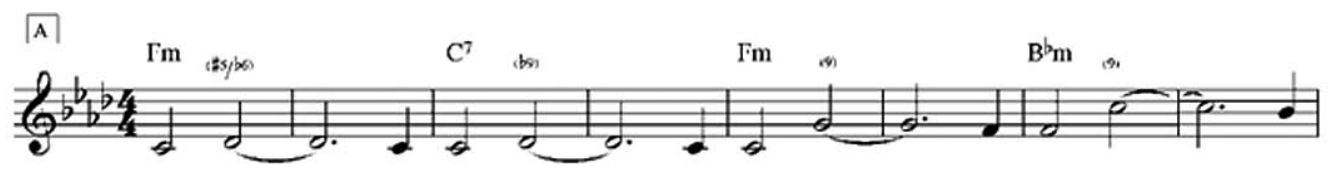

Nuottiesimerkki 4. Laulun alku (osa A, tahdit 1 - 8). Pitkä painotus soinnutuksesta poikkeavalla nuotilla (sanat: Strange dear, but true dear, when I'm close to you dear, [the]).

Lähempi tarkastelu lienee paikallaan voimasuhteiden näkemiseksi. A-osa palaa, kuten mainittua, puolikadenssilla F-mollille. Voitaisiin siis olettaa, että sointukulku "voittaa", eikä näin ollen ole pakotettu moduloimaan. A1 nostaa taas melodian askeleen korkeammalle (tahdit 25-27) ja aikaansaa melodialla modulaation kokokadenssilla As-duuriin, jolloin melodian voi puolestaan nähdä "voittajaksi" tai pakottavan laulun modulaatioon. B-osassa on vähemmän "tottelemattomia" säveliä, poikkeuksena tahdin 42 selkeä "niskoitteleva" sävel vähennetyllä noonilla (sanalla "joy"), joka laskee melodian taas puolikadenssilla F-mollille (Fesı vastaan Es-duurisointua; jälleen kerran, "joy" eli iloa niskoitte- 
lun kautta). Tämä Fes2-nuotti soveltuu myös Burnsin nousevaan kaavaan, sillä B-osa sijoittuu A1 ja A2-osien väliin. Näin nousevista lakipisteistä tulee kaava Des (A), Es (A1), Fes (B) ja F (A2).

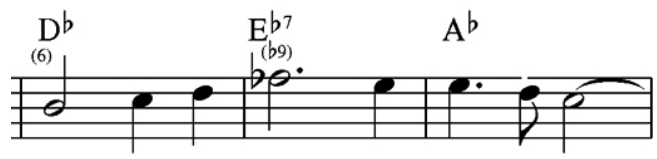

Nuottiesimerkki 5 .

Osa B, tahdit $41-43$

(sanat: [In] love with my joy delirious)

A2 näyttäisi jälleen olevan melodian säätelyn alaisena, mutta tahti 65 tuo erikoisen, aivan uuden vähennetyn septimisoinnun jota ei tähän asti ole kuultu (As vähennetty septimisointu). Alkaa vaikuttaa siltä, että soinnut alistuvat nyt melodialle, tai pikemminkin, sointukulku alkaa kokeilla omia rajojaan melodian esimerkin mukaisesti. Tässä nähdään jälleen libidinaalinen kiusoittelu: A:n ja Aı:n mukaan A2:n lopulla pitäisi olla kadenssi (tai puolikadenssi) toonikalle, mutta sen sijaan Porter lisää jännitystä lisäämällä dimisoinnun, joka ei vihjaa kadenssiin eikä varmasti toonikalle. Näin saamme pidennetyn kadenssin, jonka Porter kirjoittaa vasta kahden tahdin (sadistisen - tai kuten Allen Forte (1995: 145) sanoo - Porterille tyypillisen ironisen) viivyttelyn jälkeen. Porter luo odotuksen tunteen dimisoinnulla ja viimein antaa viimeisen kadenssin As-duurille, josta tulee viimein "voittaja"sävellaji.

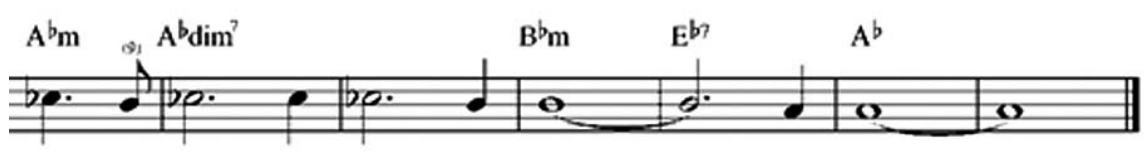

Nuottiesimerkki 6. So in Love, viimeiset tahdit $(64-70)$ sekä poikkeava dimiseiskasointu (sanat: So in love with you, my love, am I)

Lienee jo selvää, että melodia ja sointukulku ovat läheisessä vuorovaikutuksessa, mutta kumpi dominoi, kumpi alistuu? Laulun sanat, jotka Porter myös itse kirjoitti lauluun, kuuluvat eittämättä melodian vaikutuspiiriin. Tässä laulussa sanat ovat syllabisia, eikä melismoja tai korusäveliä ole (ainakaan merkitty nuot- 
tiin, mutta toki tulkinnan vapaus jää laulun esittäjälle). Mitä uutta informaatiota sanat tuovat laulun sM-tulkintaan?

\author{
A: Strange dear, but true dear, \\ when I'm close to you dear \\ the stars fill the sky \\ So in love with you am I
}

A1: Even without you

my arms fold about you

You know darling why

So in love with you am I

B: In love with a night mysterious

the night when you first were there

In love with my joy delirious

When I thought that you might care

A2: So taunt me and hurt me

deceive me, desert me

I'm yours till I die

So in love, so in love,

So in love with you my love am I

Sanat ovat eittämättä alistuvia rakkauden kohteen tahdon alaiseksi, kuten "torch" -laululle on tyypillistä (Burns 1995: 305). Varsinkin A2-osan sanoituksessa (so taunt me and hurt me jne.). Joitakin masokistisia tendenssejä paljastuu myös A1-osioista, jos uskomme Deleuzen (2006: 72) ajatusta, jossa masokisti näkee unta, uneksii tai unelmoi silloinkin kuin on hereillä ("is dreaming even when [s]he's not"). Selvästi laulun "I" on unelmoimassa "you":sta. Tämä houkuttelisi päättelemään, että melodia/sanat-yhdistelmä (laulun henkilöhahmon representaatio) on submissiivinen osapuoli laulussa, ja sointukulku olisi tätä dominoiva osapuoli, joka samaistuu kenties poissaolevaan rakastajaan jonka mielenoikkuihin alistutaan. Melodia luo kenties tahallaan "hankaussähköä" pyrkiäkseen eroottiseen ilmaisuun. Kuitenkin on tärkeää huomauttaa, että nämä kaksi osapuolta ovat 
kuitenkin vuorovaikutuksessa. Sointukulkukin antaa välillä periksi melodialle. Tämä taas puhuu sen puolesta, ettei submissiivinen osapuoli ole alistettu tai kiusattu, vaan on performatiivisesti mukana kohtauksessa pitäen samalla kontrollin itsellään. Kuten Foucault (1998: 94) sanoo, valta tulee alhaaltapäin.

Kun verrataan A-osien ja B-osan sanoituksia, B-osa näyttää muistelevan parin ensitapaamista. A-osat ovat enemmän tähän hetkeen sijoittuvia, jossa koettu rakkaus ei ole uusi mutta silti liekeissä, päättyyhän jokainen A-osio tunnustukseen "So in love with you (my love) am I" (Burns 1995: 310). B-osa on pitkälti As-duuria, ja A-osat alkavat F-mollista, As-duurin rinnakkaismollista. Tässä voisi nähdä kahden sävellajin kamppailua (Burns 1995: 315), jossa menneisyys kuvattaisiin duurissa, nykyisyys taas mollin ja duurin välimaissa. Täten nykyisyys ei lienekään niin ikävää kuin miltä alussa näyttäisi. Kenties laulajapositio nauttii alistumisestaan.

Mitä uutta sadomasokistinen tulkinta tuo Porterin lauluun? Ensinnäkin, alistuvan positio siirtyy säälittävästä, hyväuskoisesta, masokistisesta (nais)uhrista itsemääräävään eroottiseen itsetuntoon sekä voimauttavaan sensuaalisuuteen, kenties jopa viettelyyn asti. Laulu muuttuu yksipuolisen rakkauden lamentaatiosta kutsuksi (kontrolloituun) seksuaalifantasiaan luotetun, sitoutuneen ja hauskuutta rakastavan kumppanin kanssa. sm-teorian mukaisesti submissiivisen osapuolen täytyy olla suostuvainen tapahtumaan. Tässä "I" pyytää rakastajaansa kiusoittelemaan ja satuttamaan häntä (säkeistö A2), muttei välttämättä seksuaalisen kutsun ulkopuolella. Manipuloidusta, kiusatusta, jopa fyysisesti pahoinpidellystä musikaalin pääosasta löytyy viimein jonkinlainen selkäranka. Hänestä tulee manipuloija, viettelijä. Kun ajatellaan musiikkianalyysia, So in love toimii esimerkkinä eroottisesta (sM) voimasta musiikissa, ja tämän kautta voidaan tulkita myös muita kappaleita, joissa sama ilmiö toistuu.

Kun ajatellaan, että laulua voi laulaa kuka tahansa, on tässä vaiheessa turhaa alkaa erottelemaan masokistisen kokemuksen eroja sukupuolien välillä. Itse asiassa sukupuoli tulee laulussa (irrotettuna musikaalikontekstista) toissijaiseksi tekijäksi, ellei jopa ylimääräiseksi lisäinformaatioksi. Laulussa käytetään sukupuolittomia sanoja "I" ja "you", jotka voivat sinänsä edustaa subjektia ja sen toiseutta, mutta sinänsä laulu ei implikoi sukupuolta kummallakaan sanalla. Jos siis butlerilaisittain oletetaan, että subjektiin "I" voi asettua mikä tahansa sukupuoli, sM-kontekstissa "I":n positiosta masokistina tai submissiivisena osapuolena tulee määrittävämpi tekijä kuin biologinen (tai edes sosiaalinen) sukupuoli. 


\section{Submissiivinen lang ja dominoiva London}

Sedgwickin paranoidin lukemiseen kuuluva reparatiivinen osio koostuu kahdesta esimerkistä, joilla yllä olevan musiikkianalyysin paranoidi lukeminen saadaan sovellettua käytäntöön. Sovellankin tulkintaani k. d. langin versioon, jota Lori Burns (1995) on jo tutkinut, ja Julie Londonin versioon, joista voidaan vetää erilaisia johtopäätöksiä sadomasokistisella ajatuksella. k. d. langin So in Love on äänitetty AIDs-hyväntekeväisyyteen vuonna 1990. Burns (1995: 324) näkee laulun pakona miehisestä auktoriteetista vedoten langin pitkiin glissandoihin sekä tahdin 58 lakipistenuotin pidätyksellä ilman sen laskua sävellajin kvintille, kuten Schenker-analyysi tässä vaiheessa vaatisi (ks. nuottiesimerkki 3: melodia jäisi langin versiossa f2:lle).

Sadomasokistinen näkökulma tuo hieman erilaisen tulkinnan langin lauluun. Susanna Välimäki huomautti minulle graduni palautteessa Liebestod-tematiikasta, joka tukee k. d. langin tulkintaa laulusta. Sadomasokistinen näkökulma nostaa kuolleen rakastetun teeman sublimoiduksi, masokistiseksi ideaksi kuolemasta, josta tulee intohimoisen rakkauden täydellinen muoto. Henkilökohtaisesti tämä ajattelutapa häiritsee minua hiukan, sillä moni sadomasokistinen teksti alkaa keskustelulla niin sanotuista "snuff film"-pornogenrestä, jossa kliimaksi saavutetaan kirjaimellisesti tappamalla aktiin pakotettu tyttö (ks. esim. Williams 1989: 189-195). Silti, langin versiota ei tarvitse nähdä näin pitkälle menneenä. Sublimoitu kuolema on samankaltainen Deleuzen (2006: 71) ajatuksesta masokismista odottamisena sen puhtaimmassa muodossa, jolloin romanttisesta lupauksesta "I'm yours till I die" tulee lupaus jälleennäkemisestä kuoleman jälkeen. Puhdas odotuksen tila sublimoidaan elämän pituiseksi masokistiseksi esileikiksi, joka saa orgastisen loppunsa vasta, kun eloon jäänyt rakastaja/laulaja kuolee itse.

Julie Londonin (1965) jazzahtava sovitus maalaa taas aivan toisenlaisen kuvan. Laulun fraasit on tulkittu paljon lyhyempinä kuin langin hedonistisessa versiossa ja luovat täten erilaisen tunnelman. Laulajan läsnäolosta tulee lähes välinpitämätön. Tempo on myös nopeampi, ja tämä tekee lauluun kiirehtivän tunnelman. Kontrasti intohimoisten sanojen ja lähes penseän tulkinnan välillä tuo mieleen naisen, joka on pakotettu laulamaan kyseistä laulua, tai ehkä enemmänkin pilkkaa sanoituksia sekä niiden kuulijaa tulkinnallaan. Londonin laulu tuo mieleen Sacher-Masochin arvaamattoman, kylmän naispatsaan, jonka eteen masokisti heittäytyy ja jonka jaloissa itkee. Julma dominatrix pilkkaa Porterin 
melodiaa, sanoja, ja jopa tapaa, jolla kyseinen rakkauslaulu pitäisi ottaa vastaan. Hänen irrationaalisuutensa ja kylmyytensä sublimoidaan ikikauniiksi Jumalattareksi, joka ottaa mitä haluaa eikä edes viitsi valehdella tunteistaan. Hän tekee rakkauslaulusta antirakkauslaulun välinpitämättömällä asenteellaan. Vaihtoehtoisesti laulajasta tehdään fetisoitu objekti, nainen johon kiinnitetään symbolinen, Lacanilainen fallus (Steele 1996: 17). Näin laulun masokistinen idea kääntyy ylösalaisin, ja laulajan position kääntyy, jollei sadistiseksi niin ainakin performatiivisesti dominoivaksi.

Tämä artikkeli valottaa mahdollisuutta musiikin sadomasokistisesta tulkinnasta. Sen tarkoituksena ei ole mullistaa musiikin tulkintoja, vaan tuoda esille uusia näkökulmia. Sadomasokistinen tulkintatapa näyttää olevan hedelmällinen uudelleentulkitsemisen tapa, joka paljastaa sekä valtasuhteita että niiden erotiikkaa musiikista. Missään nimessä en kutsu sitä kuitenkaan kaikenkattavaksi tai ainoaksi tavaksi lukea musiikkia. Valtastruktuureihin perustuvana tulkintatapana SM-spesifiys vaatii tietyn eroottisuuden toimiakseen musiikissa, ja jos valtasuhteessa erotiikka on kielletty, on sitä vaikeampaa tulkita eksplisiittisesti sadomasokistiseksi. Uskoisin kuitenkin, että sadomasokismi tuo uutta valoa musiikin sisäänrakennettuihin valtasuhteisiin sekä tulkintaan, kuten olen tässä artikkelissa yrittänyt osoittaa. ${ }^{1}$ lations in musical and audiovisual representations sekä seminaariesitelmääni Turun yliopiston symposiumissa International Symposium on Audiovisual Performance and Embodiment (11.5.2011). Kiitokseni graduohjaajalleni Pirkko Moisalalle, Susanna Välimäelle joka tarkasti graduni ja antoi hyviä jatkoehdotuksia, sekä John Richardsonille lukuvinkeistä sekä mahdollisuudesta osallistua seminaariin. 


\section{Lähteet}

\section{Kirjallisuus}

Burns, Lori. 1995. "Genre, Gender, and Convention Revisited: k.d. lang's Cover of Cole Porter's 'So in Love.'" Repercussions 7-8 (1999-2000). Ss. 299-325.

Butler, Judith. 1990. Gender Trouble. Feminism and the Subversion of Identity. New York: Routledge. Uusintapainos, 2007.

Cusick, Suzanne G. 2006 [1994]. "On a Lesbian Relationship With Music: A Serious Effort Not to Think Straight." Teoksessa Brett, Thomas \& Wood: Queering the pitch. New York - London: Routledge. Ss. $67-83$.

De Lauretis, Teresa. 1987. Technologies of Gender. Essays on Theory, Film, and Fiction. BloomingtonIndianapolis: Indiana University Press.

Deleuze, Gilles. 2006 [1989; 1967]. "Coldness and Cruelty." Teoksessa Masochism. New York: Zone Books. Ss. 9-138.

Dyer, Richard. 1979. "In Defence of Disco." Teoksessa Frith, Simon \& Goodwin, Andrew (toim.), On Record. Rock, Pop and the Written Word, 1990. London: Routledge. Uusintapainos vuonna 1994. Ss. $410-418$.

Ellis, Havelock. 1995 [1942]. "Studies in the Psychology of Sex." Teoksessa Weinberg, Thomas S. (ed.), SEM: Studies in Dominance and Submission, 1995. New York: Prometheus Books. Ss. $37-40$.

Forte, Allen. 1995. The American Popular Ballad of the Golden Era, 1924-1950. Princeton: Princeton University Press.

Foucault, Michel. 1993 [1976]. The History of Sexuality: Volume One, The Will to Knowledge. London: Penguin Books. Translation by Hurley, Robert.

Freud, Sigmund. 1995 [1938]. "Sadism and Masochism." Teoksessa Weinberg, Thomas S. (toim.), SEM: Studies in Dominance and Submission. New York: Prometheus Books. Ss. 33-35.

Kleinplatz, Peggy J. 2006. "Learning from Extraordinary Lovers: Lessons from the Edge." Teoksessa Kleinplatz, Peggy J. \& Moser, Charles (toim.), Sadomasochism: Powerful Pleasures. New York - London - Victoria: Harrington Park Press Inc. Ss. 325-348.

Kleinplatz, Peggy J. \& Moser, Charles. 2006. "The State of Our Knowledge on sм." Teoksessa Kleinplatz, Peggy J. \& Moser, Charles (toim.), Sadomasochism: Powerful Pleasures. New YorkLondon - Victoria: Harrington Park Press Inc. Ss. $1-16$. 
Krafft-Ebing, Richard von. 1995 [1965, 1885]. "Psycopathia Sexualis." Teoksessa Weinberg,

Thomas S. (toim.), SEM: Studies in Dominance and Submission. New York: Prometheus Books. Ss. $25-31$.

Kramer, Lawrence. 1997. After the Lovedeath. Sexual Violence and the Making of Culture. BerkeleyLos Angeles - London: University of California Press.

Love, Brenda. 2000 [1992]. The Encyclopedia of Unusual Sex Practices. London: Greenwich Editions. Maus, Fred Everett.2004. "The Disciplined Subject of Musical Analysis". Teoksessa Dell'Antonio, Andrew (ed.), Beyond Structural Listening? Postmodern Modes of Hearing. Berkeley and Los Angeles: University of California Press. Ss. 13-43.

McClary, Susan. 2002 [1991]. Feminine Endings. Music, Gender \& Sexuality. Minnesota: University of Minnesota Press.

Nichols, Margaret. 2006. "Psychotherapeutic Issues with "Kinky" Clients: Clinical Problems, Yours and Theirs". Teoksessa Kleinplatz, Peggy J. \& Moser, Charles (toim.), Sadomasochism: Powerful Pleasures. New York - London - Victoria: Harrington Park Press Inc. Ss. 281-300.

Oksala, Johanna. 2007. How to read Foucault. London: Granta Books.

Peraino, Judith A. 2006. Listening to the Sirens. Musical Technologies of Queer Identity from Homer to Hedwig. Berkeley - Los Angeles - London: University of California Press.

Plante, Rebecca F. 2006. "Sexual Spanking, the Self, and the Construction of Deviance." Teoksessa Kleinplatz, Peggy J. \& Moser, Charles (toim.), Sadomasochism: Powerful Pleasures. New York - London - Victoria: Harrington Park Press Inc. Ss. 59-80.

Richardson, John. 1999. Singing Archaeology: Philip Glass's Akhnaten. Hanover - London: University Press of New England.

Schwartz, Charles. 1977. Cole Porter - A Biography. New York: The Dial Press.

Scott, Derek B. 2003. From the Erotic to the Demonic. On Critical Musicology. New York: Oxford University Press.

Sedgwick, Eve Kosofsky. 2003. Touching Feeling. Affect, Pedagogy, Performativity. Durham: Duke University Press.

Shepherd, John. 1993. "Difference and Power in Music". Teoksessa Solie, Ruth A. (toim.), Musicology and Difference. Gender and Sexuality in Music Scholarship. Berkeley - Los Angeles London: University of California Press. Ss. 46-65.

Steele, Valerie. 1996. Fetish. Fashion, Sex and Power. New York - Oxford: Oxford University Press. Weinberg, Thomas D. \& Kamel, G. W. Levi. 1995. "S\&M: An Introduction to the Study of Sadomasochism." ." Teoksessa Weinberg, Thomas S. (toim.), SEM: Studies in Dominance and Submission. New York: Prometheus Books. Ss. 15-24. 
Weinberg, Thomas D. 2006. "Sadomasochism and the Social Sciences: A Review of the

Sociological and Social Psychological Literature." Teoksessa Kleinplatz, Peggy J. \&

Moser, Charles (toim.), Sadomasochism: Powerful Pleasures. New York - London - Victoria:

Harrington Park Press Inc. Ss. 17-40.

Williams, Linda. 1989. Hard Core. Power, Pleasure, and the 'Frenzy of the Visible'. Berkeley - Los Angeles - London: University of California Press.

\section{Äänitelähteet}

k. d. lang, 2010 [1990]: So in love. Albumilta Recollection, Nonesuch

Julie London, 2007 [1965]. So in love. Albumilta All through the night, Capitol 
So in love
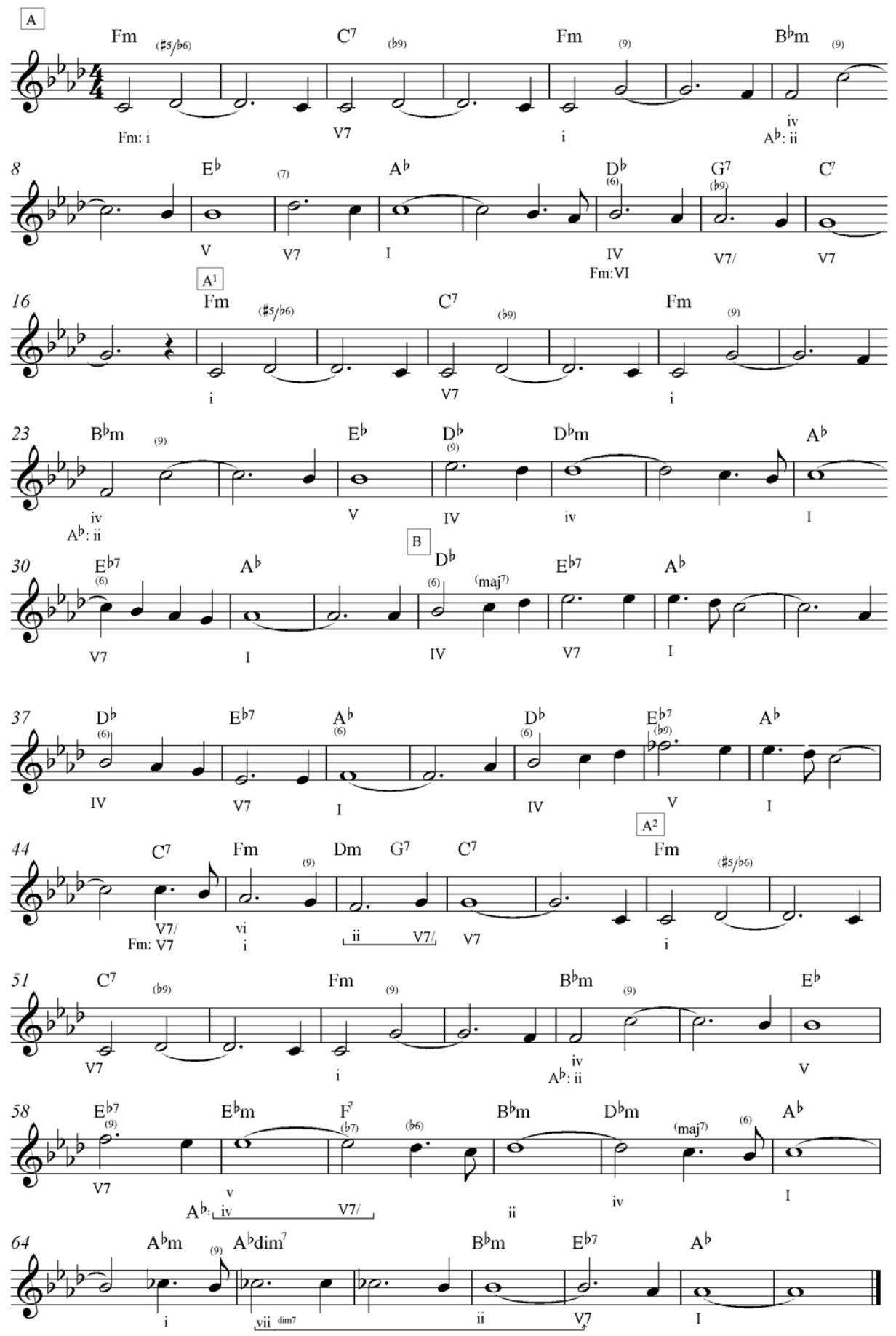

Liite 1. Cole Porter: So in love. 